\title{
Songs from taboo tongues: Experiencing first language loss
}

\author{
Abstract \\ This article illustrates the issues surrounding and consequences of losing a minority first \\ language in the process of acquiring the politically dominant language of the cultural \\ milieu (English). There are no "conclusions" in this article; however, references are \\ made to the literature on language loss and maintenance, and to practices in teacher \\ education programs which discourage additive bilingualism, asking teachers and teacher \\ educators alike to reflect on some of their own pedagogical practices.
}

\section{Canciones de lenguas tabú: Encontrarse con pérdida de una primera lengua}

\begin{abstract}
o
Este trabajo ilustra las cuestiones acerca de y las consecuencias de perder una primera lengua minoritaria en el proceso de aprender el idioma políticamente dominante del medio cultural (inglés). No hay «conclusiones» en este trabajo; sin embargo, se hacen referencias a la literatura sobre pérdida y mantenimiento de idioma y a prácticas en programas de educación de enseñadores, programas que desalientan bilingualismo aditivo, pidiendo tanto a enseñadores como a educadores de enseñadores que reflexionen sobre unas de sus propias prácticas pedagógicas.
\end{abstract}




\section{Songs from taboo tongues: Experiencing first language loss}

So, if you want to really hurt me, talk badly about my language. Ethnic identity is twin skin to linguistic identity - I am my language. Until I can take pride in my language, I cannot take pride in myself. Until I can accept as legitimate Chicano Texas Spanish, Tex-Mex and all the other languages I speak, I cannot accept the legitimacy of myself. Until I am free to write bilingually and to switch codes without having always to translate, while I still have to speak English or Spanish when I would rather speak Spanglish, and as long as I have to accommodate the English speakers rather than having them accomodate [sic] me, my tongue will be illegitimate. (Anzaldúa, 1990, p. 207)

Introduction

Until recently, most of the literature dealing with first language loss was actually concerned with language shift, particularly within minority language families and minority language communities, and often resulting in language death. Frequently studied was the gradual substitution of the source country language with the target country language within a language community over an extended period of time (Merino, 1983; Pan \& Berko-Gleason, 1986; De Bot, Gommans \& Rossing, 1991). Over several generations, families and language communities were seen to become progressively more dominant in the majority language, while each succeeding generation learned less and less of the minority language spoken by immigrant or indigenous ancestors (e.g. Hakuta \& D'Andrea, 1992; Folmer, 1992).

Consequences of language shift were defined in terms of language and culture, that is, the potential for short term and long term survival of the linguistic and cultural community (e.g., Crystal, 2000; Norris, 2004). So described, the attrition process did not take place within an individual, but between 
individuals, and therefore it seemed smooth, inevitable, and painless, a seamless tapestry of changing colours--or perhaps more accurately, a merging of colours.

More recently, there has been an interest in examining first language loss in individuals (e.g., Kouritzin, 1999) rather than focusing only on language shift. Essential though research on language shift is, it does not address individual first language loss, but rather it addresses an imperfect learning of a language by succeeding generations, as that language becomes less relevant to daily activities. As Wong Fillmore (1991) has explained in the US context, the language shift process has both accelerated and become more prevalent during recent decades, to the point at which "few American-born children of immigrant parents are fully proficient in the ethnic language, even if it was the only language they spoke when they entered school,...even if it is the only one their parents know" (1991, p. 324).

Shifting to research on individual language loss and the effects on families, with some exceptions, studies to date have tended to explore causes of language loss rather than its effects. Taft and Cahill (1989), for example, claimed that "...parents who are literate and who care about the quality of their children's language are more likely to have children who are competent speakers of the home language..." (p. 142), implying that language loss will occur in poorly literate homes in which parents are less concerned about their children's language development and education. Other researchers (e.g. Wong Fillmore, 1991; Harres, 1989; De Bot \& Clyne, 1989; Merino, 1983; Okamura-Bichard, 1985; Hakuta \& D'Andrea, 1992) have tried to statistically correlate such things as parental education, elapsed time since immigration, language status, disglossia, literacy, age, family size, types of daycare/playcare/schooling, attitudes, etc. with increased or decreased first language loss. This research was important for establishing how schooling can accelerate or, possibly, prevent first language loss, but it did not establish whether or not individuals wanted to maintain their first languages. Instead, such research begins with the assumption that language loss is a bad thing, an assumption which has not 
necessarily been proven to the politicians and administrators charged with making decisions about heritage language education--or to the teachers of immigrant children.

As early as 1983, Merino reported that Spanish-speaking elementary school children more often lost their heritage language than became bilingual. She blamed educators for being concerned exclusively with English language learning, and for relegating immigrant children's first languages to the periphery. Wong Fillmore (1991) painted a disheartening picture for minority language children learning English in American schools. Wong Fillmore found that the younger the children when they begin schooling, the greater the impact of English on their first languages, the greater the degree of language loss. Research findings seem to generally support the notion that schools play a significant role in determining the language use of minority language children (Chumak-Horbatsch 1999; see also, Kouritzin, 1997, 1999, 2000; Schecter \& Bayley, 1997).

Schools have been generally concerned to ensure that immigrant youth meet official curricular goals through the medium of English and with sufficient academic competence to succeed. What educators now need to face is the hidden assimilation agenda which allows non-dominant languages and cultures to become marginalized in public schools. Misconceptions that learning more than one language causes children to become confused, or that bilingual education programs and services do little to teach English or to promote the integration of immigrants, led to overt rejection of heritage languages in public schooling (e.g., Tse, 2001). Even more prevalent are covert forms of language marginalization among well-intended educators--non-English speaking children not being called on by the teacher, not being chosen for pair-share activities, not being allowed to negotiate a classroom task in their mother tongues, or the fiscal and time constraints preventing teachers from responding effectively to immigrant children's dual language needs (e.g., Ruiz-de-Velasco, Fix \& Clewell, 2000). Tse (2001) also points to the linguistic disparity in educational policies in the U.S., a disparity replicated in Canada. On the one hand, foreign language programs proliferate, while, on the other 
hand, heritage-language maintenance programs are largely ignored by practitioners and policy makers, meaning that immigrant children who are not able to learn a second language and perfect their first languages at public cost are not equally served by the education system (see also Kouritzin \& Mathews, 2002).

In a compelling argument against the status quo in schools, Wong Fillmore (1991) and a group of associated researchers argued that L1 loss could lead to inability on the part of the parents to socialize their children, to family disunity, to family violence, and to academic and social failure for the children. In that article, she related one story which, though anecdotal in nature, resonated with my experiences, and impelled me to explore individual first language loss:

One of them [interviewers] told the story of a family that had been referred to county social services after the father was accused of abusing his children. Someone at school had noticed bruises on the children. When the children were questioned, they admitted that their father had beaten them with a stick. The children were taken into protective custody, and the father was brought in for questioning. The story that unfolded was tragic. The family is Korean, and its language is one that requires the marking of many levels of deference in ordinary speech. One cannot speak Korean without considering one's own social position and age relative to the position and age of one's addressee because a host of lexical and grammatical choices depend on such matters. It seems that the children in this family had stopped speaking Korean, although the parents spoke little else. Everything was under control at home however, even if parents and children did not communicate easily with one another. Then one day the children's grandfather came from Korea for a stay with the family. Because Grandfather did not speak English, the father ordered the children to speak to him in Korean. They tried. They used the Korean they could remember, but it was rusty. It had been a long while since 
the children had spoken the language and they had forgotten little things, like the intricacies of the deferential system. They used none of the forms that children must use when speaking to an honored relative like their grandfather. The grandfather was shocked at the apparent disrespect the children were displaying towards him. He did what the situation called for: He scolded his son--the children's father--for not having trained his children properly. The father did what the situation required of him: He punished the children--with a stick-- for their rudeness and disrespect (p. 344).

In addition to putting the focus on the consequences of language loss rather than the effects, this story puts a human element into research on first language loss. It demonstrates how a bad situation can result from several people trying to what is morally right--in different linguistic and cultural frameworks. It also reminded me that while statistics and experiments convince institutions, policymakers, and governments, stories convince individuals. Therefore, in order to change people's minds, in order to change people's hearts, we must engage them with other people's stories.

\section{Methodology}

In this article, I draw on three "found" poems to illustrate the value and importance of stories of experiencing first language loss to our embodied understanding of its impact in people's lives. These stories-in-poem emerged from life history data (Kouritzin, 2000a) collected in previous research (Kouritzin, 1999) viewing language as a constantly metamorphosing intersection between linguistic elements, identity, culture, history, reality, information and communication. Acknowledging the interdependence of language, identity, the construction of reality, and the individual, I constructed retrospective life histories with people, primarily adults, who described themselves as having lost their first languages, continuing to collect life history narratives until I reached what Bertaux calls a "saturation of knowledge" (1981, p. 37). Participants were recruited through a message in an editorial column in a local newspaper asking for volunteers. Before the first interview, by telephone, I explained 
the subject of the research (language loss) and explained the methodology (life history). Beginning with five participants, I interviewed approximately twice a week, and transcribed interviews immediately. The first interview question was, as the participants were forewarned, "tell me about your life from a language perspective." Once each initial interview was transcribed, I wrote questions and underlined passages for further comment on the transcript, a process I followed with all successive interviews. I shared the transcripts with participants at their next interview, and we worked through the questions I had written together. Consequently, after the first interview, research participants were all asked different questions. I ensured that interviews were at least two weeks apart so as not to intrude too much on the participants' lives. Interviewees contributed between 3 and 5 audio-taped interviews, each of approximately two hours duration.

In this manuscript, I have chosen three stories--one European, one Asian, and one from an endangered Indigenous language speaker. I began by inserting all of the transcripts into the first one, in order to maintain the chronology of the original narrative. I then separated each transcript into sections according to the natural breaks and patterns--such as intonation units, breathing units, natural pauses-which were naturally present in the audio tape. I discovered that the result resembled poetry. Each time I reread the transcripts, I found myself whittling away at the texts, trying to leave only the words or phrases that, to my way of thinking, most accurately represented the ideas, and the flow of the story. At times, I reordered the sections, building a structure based not the chronology of the participants' words, but rather a structure based on meaning and ideas. In many ways this was a more intrusive form of editing than I had engaged in previous analyses, but, I believe, no more authorial, having no more authority. In short, in keeping with the literary principles of found poetry, I deleted words, but did not add them; I re-ordered text to make symbols or themes more prominent--or even, some may argue, invent certain themes or symbols; I changed pronouns to nouns at times to make the referent clear; and I used only speech text that was in the transcripts. 
I also tried to ensure that the flow of words accurately conveyed the sense of the way each speaker used language. Therefore, the words of Minette in the found poetry below remain in the metaphoric language is characteristic of her speech, and also of her position as a columnist. The terse sentences, and sometimes harsh expressions of Naomi are similarly attributes of her speaking style, as is the melancholic rambling rue of James. I cannot be sure that the poetic expression of their stories below would be how they would choose to represent themselves, but it does evoke for me the images and speech mannerisms that they represented to me. To achieve the purposes each participant had in sharing their stories with me, knowing I was "doing research" and knowing that I would share their words with others, I cannot improve upon their thoughts, expressed in their own words. These "found" poems I will therefore, fittingly, present as "findings."

\section{Findings Found}

\section{$\underline{\text { Naomi }}$}

\section{In Tahsis,}

one of the internment camps that's beyond Hope... ${ }^{1}$

that's where I was born

That's why I was born there; there was no place else to be born

I think the building is still standing

It was called the hospital, but it was basically a barn

I don't go around telling people where I was born

It's not that I'm ashamed of it;

I just don't think a lot of people would understand

They don't know the history of Canadian history

We wanted to forget we were Japanese...

because we were still the enemy after the war

I can remember being called a dirty Jap; I can remember that distinctly

The strongest recollections are of racial slurs and things being said,

and so I guess it colours the way I look now

I see KFC on the bathroom walls.

I thought KFC was Kentucky Fried Chicken,

but it's Kill F g Chinks

And I said "they're going to survive"

"They're going to be stronger than you because of it"

${ }^{1}$ In the geography of southern British Columbia, Hope is the starting place for highways leading away from the densely populated coast region. Beyond Hope is wilderness. 
I think:

"those things they are yelling at you are nothing compared to what was yelled at me... and I survived" I just couldn't figure out why they were yelling that at me

I wasn't going to speak Japanese at all; I would only speak English

My language skills now are about, I would say, a six year old

I couldn't speak my language and I was better off for it

I knew I had to work harder and do better because I was a minority

They looked that I couldn't do as well, so I always worked harder

So we sort of buried it, forgot it

It's amazing how easy it is to forget a language

One of my mother's sisters repatriated--what's that--during the war

My mom's other sister was embarrassed...

would not allow her boys to speak any Japanese

my oldest cousin married a Caucasian....

after twenty years he is now going around with a Japanese Canadian girl

It just didn't work, so now he's going back

He has rerooted himself, as if he's sort of backtracked rather than gone on

It was all in Japanese until my grandmother died

She was always there.

She always wore a dress

She always wore her hair coiled up

People were tiny in those days, not only short, but tiny tiny tiny

Many times, I'll be at a funeral,

that's when I find my lack of language skills

My mother and dad spoke Japanese, when nobody else was around

The soundtrack of that whole process has to be in Japanese

because we were doing the Japanese thing

They're still stuck in the Japanese that they spoke when they first came over

I responded in English as early as I could

I didn't have little kids to do baby talk with

There were stores still after the war that my parents weren't allowed into

I don't think words like discrimination were really talked about;

it was just a fact of life

Discrimination was something that happened

and that was the end of it

You forgot it because you wanted to be Canadian

The quicker you got over your traditions, the better it was

But, she'll always be a friend because at that time she allowed us into the store

I maintain my daughter has to do well

because I'm Japanese Canadian

and I don't want her to embarrass me

I probably try harder to be the perfect parent 
I don't want her friend's parents to say

"Jin's the way she is because her mom's a Jap"

I'm still very aware of that in my mind

I want more for my daughter than my husband does

because he's not going to be called a dirty Jap

Because he's white and six foot four

We've come full circle

I wish I had maintained it, but I know why I don't

If I really wanted it, I wouldn't have said I don't have the time

If I really wanted it badly enough, I would have gone to school and learnt it

I don't think I would dare to speak another language

strictly in terms of communicating that I do in Japanese

For the Japanese, what comes out, comes out

I figure they can figure it out themselves

I don't think we were entirely comfortable

at having Caucasian friends into the house

I can't ever remember having one of my friends in for dinner

Because eating is private

My parents weren't welcome into Caucasian homes

We worked as a community within a community,

Waiting to see what the other kids were doing,

and then figuring out what they did

that's hard when it's a small town

It was just Indians and Caucasians and Japanese

We were ranked some place in the middle

Because the Indians were mostly all drunk

We were more respectable than that

The Japanese Canadians all worked

We all tried harder to be respectable

The Indians didn't seem to care, but we cared a lot

We wanted to fit in so badly

People would stare, say that we were plotting things

That's where the language got lost

We wanted to hide it, hoping that we would fit in more

People have very strange ideas about how I live

I am a little bit more considerate of people

I'm a lot more intolerant

Japanese people are more intolerant;

They have a superiority complex because they don't get off the island very much

I have an inferiority complex

I always had to do a little bit better than the next person

because I had the stigma of being a Japanese

so I had to prove that it wasn't all a negative thing

I don't like to hurt people's feelings; 
I would rather just not have anything to do with them than to tell them the truth... because if I tell the truth, they might yell at me

The way they looked upon us, I realized that it was not good to be Japanese

The years rolled by. People forgot

Ten years after the war, people would warm up and be your friends

I still feel really uncomfortable around older people who fought in the war

I choose my friends very carefully

The fellow across the street from me is a vet, and he's very good

Around Nov. $11^{\text {th }}$, I will avoid seeing him, especially if he has his blazer on

The suspicion is in my mind that I think that he is suspicious

I'm not being fair to him,

but still it's there

If Japan hadn't risen from the ashes and the rubble

I think a lot of suspicion would still be around toward the Japanese

I feel much more comfortable with the Japanese

I have moments in my life, in my adult life,

when I have felt uncomfortable with Caucasians

My own identity, I think it's a dying race; it's not going anywhere

More and more Japanese Canadians, the redress generation, will be marrying Caucasians

My daughter thinks nothing of saying

"oh are you a halfie? What halfie are you?

It's nice that my daughter's generation is like that

It wasn't necessarily when we were born,

it was the fact that our parents had suffered

We were displaced

I have always voted NDP because they got us our vote

I will never vote Liberal

that was the government that had our communities moved

900 miles from the coast

Redress wasn't won money; it wasn't a bonanza

a whole generation lost the opportunity to become professionals

People lose fortunes all the time.

I don't think that's as jarring as the loss of opportunity

the loss of looking after your family in the way you want

in the way that you had dreams of looking after your family

We didn't have very much money

because you started with nothing after the war

My dad worked steadily

Caucasian families took holidays,

but we just never had the money to take holidays

The loss of opportunity is what people who were interned will never forgive or forget

\section{$\underline{\text { Minette }}$}


I'm a journalist

I have always loved words,

worked with words, enjoyed words,

played with words

I don't know what my first word was but it was in French.

My father is nearly eighty... he was born in the Hague.

His first language is Flemish, his second language is French.

My mother who is now dead spoke eight languages;

French was one of them.

She spoke German, Austrian, English, Yiddish, let me think what else,

Hungarian, Yugoslavian, and something else I can never remember

Uh, my father is also a writer, or he was.

He wrote a book... I couldn't even read the title.

It's all about the things he did in the war, and I can't read it.

It was published in Belgium, and I can't read it.

So that's a bit of a shame.

I was estranged from my father for about six years.

We had an argument, a bad one.

And whenever I heard French during that period I was very annoyed.

Earlier this year --my husband died

among the many letters and cards of condolence,

were letters, full letters,

from my relatives in Belgium,

all written in French.

So I sat there

with my pen in one hand

and my French/English dictionary in the other

to try to thank them

.... and to tell them what this loss has meant in my life.

As a child in east Vancouver

I would have spoken French at home,

but my parents tried very hard to assimilate.

they were trying very hard to be "good Canadians".

"Good Canadians" means that you talk to the neighbours,

to the shopkeepers,

and you try to be almost like everyone else

That was a very sinful definition.

My parents brought very little with them, almost nothing.

My father had to make furniture from orange crates

we were very very poor,

as were so many immigrants when they came here.

So, the sort of culture, capital $C$, came in much later

my parents were too busy trying to survive. 
Canada was raw and green and lots of jobs and opportunities.

We didn't have a car. We didn't have much money.

My father, to his great credit, took any job,

he dug ditches, he worked for the Post office and he would walk to all those jobs.

So there wasn't really a lot of time for socializing

As a child, with French visitors to the home

I was trotted out like "this is Minette"

I would have my piggy bank in my hand

go around to each adult and I'd say "hello"

....... and they'd drop their dime in and then I'd leave.

When I started grade one

extraordinary difficulty with written English

I was teased...I'd forgotten about this;

I was teased in my childhood

because I spoke with a very heavy European accent;

in fact the accent that you're hearing now, the Canadian accent, is artificial.

It's like a layer of veneer;

don't get the idea that I was some sort of Baudelaire or something in French, I spoke at the level of a two and a half year old

it's very sad losing your first language because you lose your roots,

your lose your connection to the people who remain behind

it just sort of happened

through benign neglect

I have no link to them,

it's a whole family lost,

because of geography, distance,

and to a very large degree language,

because there's a telephone, there's a fax, there's a pen,

and I can't avail myself of any of those things

I will say that's the language that has cleaved us.

Language is an important part of society,

linking with other people,

reaching out to other people

drawing them in to you.

I'm sorry that I didn't have my mother's gift.

sometimes she would speak all eight languages in one sentence

sometimes she would meet a boyfriend of mine that she wouldn't like

she would mix up her languages deliberately

she would say "ah, you're such a charming shoyzau"

which means little creep,

she would say "you are such a meeznik"

meaning you are so ugly and cross-eyed.

And he would say "well thank you, thank you very much". 
I have this sense, rightly or wrongly,

the language is locked back there in my brain

it's not really forgotten; it's just sleeping.

The language is there,

locked with other memories of childhood.

Loss happened so gradually,

like an old pair of underwear slipping down,

the elastic goes and goe

you're not really conscious of it.

Just a loosening of the bond.

I remember a relative coming over from Belgium once.

A young man, of course,

I immediately fell in love with him

He asked me to pass the salt...

he asked in french..

and I focused intently on his every word...

I said "no merci"

so then he laughed.

I wish I could come out with

some of those nutty brown rich wonderful stories

I'm not even particularly interested in our family tree

I'm not particularly interested in history

and I'm the poorer for it I suppose.

But that's an honest answer,

I don't know any of those stories.

I oppose,

and this is terribly red-necked of me,

I don't like to see the French channel on TV much.

I'm disappointed in myself about that;

it's maybe five cents a year from my tax dollars

but I'm one of those people who.... sort of thinks

"we're in this country, let's speak the language of the country,"

at the same time, my brain fully supports

the right of Punjabis and Sikhs, and people from China and anywhere else

to speak their own languages

I shouldn't get so irritated when I call Quebec,

and I do get irritated, very irritated,

at the arrogance of the Quebecois, the French-speakers.

I should have more understanding of more people

in both an emotional and a linguistic sense.

When you come to a country

it's like a marriage.

You can't expect total devotion

very deep feelings 
for the first year or two.

You don't understand.

You think you're getting it,

but you don't understand

the depth that comes with years

and with maturity in a relationship.

It's about communication.

And shared experiences.

one difficulty of coming to another country,

is that everyone else remains in the other country.

I come from somewhere else.

I feel different

I want to feel accepted,

I'm proud of it too.

It's nothing to be proud of;

it's an accident of fate and geography

Now that I've experienced profound grief,

due to the loss of my husband,

now I understand grief,

my grief is like a low-lying chronic sadness.

That's the way I can also describe the loss of a language.

It's a regret. I can't find a word.

It's like a... what might have been.

it's a lost opportunity...

It's an unfulfilled

it's a sense of incompletion.

but not nostalgia,

but you want something.

Maybe the kind of feeling that an adopted child has for the biological mother?

\section{$\underline{\text { James David }}$}

I was born in 1940 in a small village in South Wales,

on the north edge of the South Wales coal fields....

Welsh was the first language,

the language of the hearth,

my parents were both of strongly Welsh background,

family consisting of ministers, Welsh speaking, religion, chapel services and so on.

My early years involved learning English as well

Speaking English within the family was considered to be something of an affectation.

Play in the schoolyards always involved speaking Welsh.

I remember games occasionally in which one would pretend to speak English, with a strange accent

One used to pretend that one knew more English or more French than one really did,

I do recall a great problem that I had in the early years with stuttering...

I was forced to change from writing with my left hand to writing with my right hand in school;

it created a pattern of stuttering which occasionally when I am tired, recurs.

Anyway, I remained fluently Welsh speaking and English 
After leaving Wales I never really had an opportunity to speak Welsh at all.

I've slowly been losing it.

I have five... well four.... children surviving.

And not one of them speaks Welsh.

I haven't spoken Welsh for I guess it's now thirty five years

probably lost a great deal of my language by now.

I can still read it, but I do have to do a double take occasionally

the language is still obviously very much alive

Mine will presumably die with me.

I have mixed feelings about that. I wish some of my kids had... but there we are.

I don't find myself sort of romanticizing or agonizing, which is the famous Welsh....

That's the romantic Celtic thing

My spirit in a sense has transferred here with the kids,

my focus is very much in this country.

As soon as I came off the plane in 1963 and I smelt the cedar at Vancouver Airport,

I thought "my God, this must be the biggest pencil box in the world!"

I've never recovered from it; I love this country.

It may be that I'm letting my own language go too easily

I feel very very fortunate to be living in this part of the world.

I am probably romanticizing it;

it's the spirit of the Celtic wanderer, you know, the adventurer,

an idealizing picture of what being alive is all about.

I think comes from the rather speculative romantic nature of Welsh poetry,

Welsh language

I don't see that as failure; I see that as a transcending kind of quality,

which equipped one to deal with life.

the real elements of the conversation are best perceived when one can't hear the individual

words detract from understanding

I remember six of us, five friends of mine

Suddenly Winford, who in a financial sense was the most successful of the six of us, because he'd

become an undertaker,

spoke I guess a 160 line poem which he'd

this incredible tradition of expecting people, regardless of station in life

having a lyrical fluency of some kind.

I've left all that behind.

I do miss now and again the cut and thrust of tying into somebody else over issues of language usage,

of responding to a certain line with another kind of line

that sort of sets it off

If you proceeded with Welsh language and Welsh literature which I did,

then one wasn't able to do Latin and one's access to,

Oxford or Cambridge, or to medicine, was automatically gone because you had to have Latin.

I recall a small number Catholics who certainly wouldn't be able to speak Welsh

I guess one would look askance at them,

somewhat self-righteous.

there were some students at the school who could speak Welsh, 
some who couldn't and who in effects were monoglots.

And there was a certain amount of social tension sometimes

Welsh speaking people were considered a pidgin culture,

I would have put that down to ignorance on their part

I probably considered them ignorant

I mean for not knowing the Welsh

perhaps there was a parallel acquisition of languages,

but a very heavy emphasis at home on Welsh,

one could have more fun in Welsh,

could get more randy in Welsh, could be more honest in Welsh, could be more frank in Welsh,

could be more real in Welsh;

one really existed in the context of Welshness and.....

it shifted to English.

One point when our rugby team went to play against an English boarding school

we stayed in one of the homes

in the morning we were offered some poached eggs

they had a gas stove and these poached eggs stank of natural gas

the taste of that meal, the strangeness of it,

the foreignness of it,

enshrined the English point of view

I had this strong aversion for all things English

at the age of 30, 35, I rediscovered the English language,

or truly discovered the English language

I've described it now and again as falling in love with the language.

It's almost as though emotionally I've taken it on.

We lost our oldest boy in a car accident, about ten years ago,

and this process of identifying with the English language,

its poetry, literature and so on, has been peculiarly intensified since that time.

Identifying and having access to the English language has been a life saver to me.

I see it that way now in retrospect

When I get really down ...

circumstances surrounding my oldest's death,

I find myself going back to the Welsh language

and speaking Welsh poetry to myself,

and speaking to him in Welsh, almost as if the language...

almost as if my emotional center was clustering around my early upbringing,

My Welshness.

I'm so impatient with people who worry about children being expected to know a second language, I think to myself "you don't even understand these enormous continents of understanding and of transcendent experience that you're denying them"

I personally don't see the merits of monolingualism

I occasionally refer to the circumstances in this country

when I look at the way in which the English language is used 
and the way the French language is used--

a bi-semi-lingual country masquerading as a semi-bi-lingual one

I think if everybody in this country was forced to learn French and English,

Cantonese and English,

French, Cantonese and English,

and got on with their darn lives, then,

the better off we'd be.

My dad grew up in a small village called Camplindeth

they had a farm outside the village.

children were discouraged from speaking Welsh in school.

a child who spoke Welsh in the playground was given a type of amulet to hang around the neck, and then the next person who spoke Welsh,

he was able or she was able to hand on this Welsh knot, to be stigmatized in the playground.

My father does remember being beaten for speaking Welsh in that context.

He also had a very ingrained memory of

one of his brother's best friends going away to university,

coming back after graduating and teaching in the school,

while my father was by then a student,

and he punished my father for speaking Welsh;

it still stung as an enormous kind of betrayal.

On my mother's side there were a number of people who wrote poetry,

there was one who won the Bardic chair;

there was a strong tradition of being literate in the Welsh language.

And the church was a strong influence,

conducted in the medium of Welsh.

I guess for my father having been punished with speaking Welsh within that kind of context

this has all the hallmarks of being the roots of ethnic confrontation,

and symptoms of ethnic confrontation.

I think it was something along the lines of what nowadays they would call a cultura-side-getting people to conform

Because education in the formal sense,

swept across Wales a little later in the formal sense than it did across England

English was certainly being pushed as the language,

people were expected to be able to speak English as a mode of social mobilization,

creating an educated work force who could read instructions in English on machines.

English was there,

though there were still memories of the fifteenth, sixteenth, seventeenth centuries,

when in the face of the Anglican church,

Welsh people very often,

especially along the border counties,

resorted to Catholicism,

and to learning Latin,

as well as speaking Welsh as their native language,

as a way of resisting Anglicization.

There's a very long tradition of resisting the Anglicized

and it still goes on-- 
because, you see, whilst we were formally considered a conquered people, here we go, in our heart of hearts,

in a Welsh person's heart of hearts,

there is no sense of having been conquered.

I'm two people....

between a real nostalgia and sense of loss for not speaking Welsh,

and yet a resistance to it.

I'm hopelessly romantic about it,

but that occurs within an insisted framework that I don't have to share with anybody.

My parents would speak English sometimes,

depending on the circumstances,

somebody visiting who couldn't speak Welsh, uh,

In school you had to start reading in English of course,

because one was being prepared to be bilingual,

I guess though I do note that I have a rather idiosyncratic way of speaking English;

it goes on and on and is a bit tortuous and all that.

And perhaps it has some signatures on it that indicate that it's my second language;

People do say now and again "yes well you're Welsh, that's why you say it this way."

I wouldn't dare go back to Wales and speak English for a sustained period of time.

It would be absolutely wrong because the signal it would give would be...

"oh, he thinks he's better than we are. That he's now graduated from the Welsh".

The neighbours, whoever, would think that "he's above it all."

You see people would go away to universities from the village

onto Oxbridge or somewhere,

and they'd come back at the end of the semester,

first term, and they'd have feigned accents,

Oxbridge accents; it's the worst thing in the world you could possibly do.

It was considered so insulting and so bad,

people who did that were a write off anyway.

I have never worked on my accent;

I've never bothered to try and change it;

it's become Canadianized, Anglicized;

it's been 33 years after all!

But I've never worked at it,

and I still have a Welsh accent I recognize it when I hear myself on tapes.

I was never trying to change my accent.

One shouldn't squander one's life on stuff like that.

You have to realize that to feign an accent is such a self-annihilating thing to do

in terms of one's sense of oneself,

or the seemliness of one's accent for God's sake,

of one's speaking voice,

to feel that you needed to change it?

That's awful. 


\section{Discussion}

A number of motifs echo (to me) in the found poetry, perhaps because of my own social position. I am a second generation immigrant who did not learn her heritage language, Russian, out of shame, or fear, or feelings that it would not be useful; in any event, my linguistic landscape did not include Russian. I am the mother of visible minority children who speak what appears to be their heritage language (Japanese), but is not the indigenous language of their people (Tokunoshima-ben); their father did not fully retain his heritage language after it was schooled out of him, becoming dominant in Japanese instead. The motifs which seem the most powerful to me are those that resonate with what I believe and what I have experienced. Therefore, I invite dissent.

The major themes which play out in these three found poems do represent the larger data archives. What appear to be most salient are the themes which have to do with schooling and identity development at school. There is resentment, anger, and grief that school policies and programs did not encourage, did not even permit, the use of first heritage languages. There are strong, frequent, echoes of never really fitting in, of never being part of a group. The failure to recognize languages other than English bred shame in the participants, and forced them to conceal their heritage identities at school, a practice that eventually became lifelong. What is most painfully clear is that identity and language "decisions" made by children in the face of an assimilation-oriented dominant culture, are decisions later regretted. These participants seem to ask themselves "why did I let this happen? Why did anyone let this happen?" when it is no less than human nature to do what is easier and less painful, to try to fit in, to "go with the flow." These participants were being good Canadians, and good Canadians in English-speaking Canada speak English.

Related to this idea, people who lose a first language as children understand later, when they are older, how much they have lost. As they age, familial connections become more important, confirming the adage "blood is thicker than water." Family stories, roots, ancestry, all of these become 
increasingly important as our concepts of time and place and universe develop, and we realize our own insignificance in the world. Perhaps wishfully thinking, or perhaps justifiably curious, they seem to believe that the lost first language is still there, trapped somewhere in the folds of the brain. Minette, in particular, volunteered to participate in any research project which experimentally tested her theory that she could be fluent in French again in six months, but that it would take longer for someone with no childhood history in French. She seems to suggest that the feeling for the language that we all cite when we are editing someone else's writing ("that doesn't sound right"; "that doesn't look right"), the language monitor that guides our language use and intuitions, is still intact and buried somewhere in her mind.

One of the participants in the larger research project explained to me that "in order to understand the circle, you have to understand the space outside the circle" (William, life history storyteller), by which he meant that in order to understand having a language, you had to understand losing a language. He argued, essentially, that it was important for people to feel and to resonate with the experience of losing a first language, or with the experience of having one's language be colonized, in order to fully appreciate what it means to have a mother tongue, to speak the language of one's heart, to be heard (not merely listened to, but heard) speaking in one's own voice.

Apart from listening, my responsibility is to use this knowledge of the consequences of language loss to better understand my own teaching practices, and those I have viewed as a teacher educator. All of the participants involved in my research project talked about the impact of schooling on their family language usage. Language loss did not begin until formal schooling began--and then through design or benign neglect, English replaced the mother tongue instead of being added to it (e.g., Wong Fillmore, 1991, p. 335). School children and school practices encouraged minority language 
speaking children to develop shame, while school work and school friends became linguistic and cultural invaders (Kouritzin, 1999).

\section{Conclusion}

As a teacher and a teacher educator, I am then led to question some of the pedagogical practices we teach to pre-service teachers in the Canadian context. Because more than half of the world's population is bilingual (Harding \& Riley, 1986), bilingualism cannot be considered rare, harmful or unusual, yet teacher education programs throughout Canada do not require courses in bilingual development, in additive English second language curricula, in multilingual (as opposed to multicultural) education. Gaining little understanding of the purpose of teaching English as a second language (bilingualism for minority language students, not monolingualism in English), pre-service teachers then replicate excellent practices that they viewed in schools or studied in courses, without consideration of the consequences, without viewing them from a minority language perspective. What is "home reading" to a family struggling to maintain a first language in the home, if not cultural invasion? What are "home visits" to minority language families if prior warning is not given and a translator is not present, if not the humiliation of parents being forced to speak a second language badly in their own home? What is rejecting languages other than English and the substitution of works in translation in the stories we read in classrooms, if not rejection of minority language children's identities? How are minority language families to assist with homework in English and still maintain a focus on the first language, placing parents in a double bind of having to support competing languages (e.g., Kouritzin, 2000b)? Such school practices may lead to language loss, which in turn can interrupt the stages of ethnic identity formation described by Tse (1998), leaving children unaware, or ambivalent, unable to incorporate their ethnic or linguistic identities with a strong immigrant identity. Families with sufficient socioeconomic resources find themselves able to both hire tutors outside the home to assist with English language homework, and to engage with the minority first language in classes and communities (e.g., 
Séror, Chen \& Gunderson, 2004; Guardado, 2002) or by actively pursuing transnational lives, meaning that loss of ethnic identity and loss of heritage languages runs the risk of being the lot of the poor. Given the well-known and well-established links between economic advantage and bilingualism (e.g., Baker, 2000; Harris, 1998; Beaudin, 1998; Breton, 1998), and those between cognitive advantage and bilingualism (e.g., Cummins, 1996; 1989; 1984; 1979), we must recognize that not allowing minority language children from socio-economically disadvantaged homes to reap the benefits of a bilingualism which should be their birthright is socially unjust.

In sum, educators need to (1) realize that first language loss is a possibility, and ensure this information is shared with the families of language minority students, (2) understand that there are consequences for families, and for individuals (e.g., Kouritzin, 1997; 1999) if children lose heritage languages that are spoken in the home, (3) promote bilingualism for all students and multiculturalism for all students, not viewing these as "just for immigrants," but rather as a deeply-held societal value, (4) invite newcomer parents and immigrant communities to be part of the language planning policies for education that affect their children, and ultimately their families, (5) encourage bilingualism in staff and faculty (which does not equate to adopting hiring practices which privilege bilinguals, but rather fostering an environment where additional language study is valued), and promote multi-language use in schools, and finally, (6) educate native English speaking students, parents, and educators about the advantages of learning an additional language, educationally and socially for all children.

At the same time, however, it is important to realize that none of the participants in this article or in any other research project that I am aware of suggest that English is unnecessary, nor do they complain about learning it (see, for example, Tse, 2001; Wong Fillmore, 1991). Rather, participants in this, and other, studies suggest that there are consequences for replacing a language with another one in terms of family cohesion (tension develops between generations in a family), psychological well-being (the experiences of being marginalized in both cultures), and educational achievement (e.g., the 
difficulties stemming from becoming non-standard or speakers of two languages, the inability to attain grade level norms in academic subjects later preventing immigrant students from entering tertiary education)--the negative consequences stem from the loss of the mother tongue, not from the learning of English.

\section{Acknowledgment}

I would like to thank the Social Sciences and Humanities Research Council of Canada for supporting the research on which this article is based. I would also like to thank the anonymous reviewers for their encouragement and suggestions.

\section{References}

Anzaldúa, G. (1990). How to tame a wild tongue. In R. Ferguson, M. Gever, T. Trinh, \& C. West (Eds.), Out there: Marginalization and contemporary cultures (pp. 203-211). Cambridge, Mass.: The MIT Press.

Baker, C. A parents' and teachers' guide to bilingualism, $2^{\text {nd }}$ edition. Clevedon: Multilingual Matters. Beaudin, M. (1998). The contribution of a minority to its region: The case of the Acadians in New Brunswick's south east. . In A. Breton (Ed.). New Canadian persepectives: Economic approaches to language and bilingualism (pp. 185-222). Ottawa: Department of Public Works and Government Services Canada.

Bertaux, D. (1981). From the life history approach to the transformation of sociological praxis. In D. Bertaux (Ed.), Biography and society: The life history approach in the social sciences (pp. 2946). Beverly Hills: Sage.

Breton, A. (1998). An economic analysis of language. In A. Breton (Ed.), New Canadian persepectives: Economic approaches to language and bilingualism (pp. 223-257). Ottawa: Department of Public Works and Government Services Canada. 
Chumak-Horbatsch, R. (1999). Language change in the Ukrainian home: From transmission to maintenance to the beginnings of loss. Canadian Ethnic Studies, 31, 61-75.

Crystal, D. (2000). Language Death. Cambridge UK: Cambridge University Press.

Cummins, J. (1996). Negotiating identities: Education for empowerment in a diverse society. Ontario: California Association for Bilingual Education.

Cummins, J. (1989). Language and literacy acquisition in bilingual contexts. Journal of Multilingual and Multicultural Development, 10, 17-32.

Cummins, J. (1984). Bilingualism and special education. Clevendon, UK: Multilingual Matters.

Cummins, J. (1979). Linguistic interdependence and the educational development of bilingual children. Review of Educational Research, 49, 222-251.

De Bot, K. \& Clyne, M. (1989). Language reversion revisited. Studies in Second Language Acquisition, 11, 167-77.

De Bot, K., Gommans, P., \& Rossing, C. (1991). L1 loss in an L2 environment: Dutch immigrants in France. In H. W. Seliger and R. M. Vago, (eds.). First Language Attrition (pp. 87-98). Cambridge: Cambridge University Press.

Guardado, M. (2002). Loss and Maintenance of first language skills: Case studies of Hispanic families in Vancouver. Canadian Modern Language Review, 58(3), retrieved from http://www.utpjournals.com/product/cmlr/583/583-Guardado.html on October 10th, 2005.

Hakuta, K. \& D’Andrea, D. (1992). Some properties of bilingual maintenance and loss in Mexican background high school students. Applied Linguistics, 13, 72-99.

Harding, E. \& Riley, P. (1986) The Bilingual Family: A handbook for parents. New York, NY: Cambridge University Press.

Harres, A. (1989). 'Being a good German': A case study analysis of language retention and loss among German migrants in North Queensland. Journal of Multilingual and Multicultural 
Development, 10, 383-400.

Harris, R.G. (1998). The economics of language in a virtually integrated global economy. In A.

Breton (Ed.). New Canadian perspectives: Economic approaches to language and bilingualism,

(pp. 35-88). Ottawa: Department of Public Works and Government Services Canada.

Kouritzin, S. (1997). Cast-away cultures and taboo tongues: Face[t]s of first language loss.

Unpublished doctoral dissertation, University of British Columbia, Canada.

Kouritzin, S. (1999). Face[t]s of first language loss. Mahwah, NJ: Lawrence Erlbaum Assoc.

Kouritzin, S. (2000a). A mother's tongue. TESOL Quarterly, 34(2), 311-324.

Kouritzin, S. (2000b). Immigrant women redefine access to ESL classes: Contradiction and ambivalence. Journal of Multilingual and Multicultural Development, 21(1), 14-32.

Kouritzin, S., \& P. Mathews. (2002). Policies affecting ESL instruction in Manitoba. Canadian Journal of Educational Administration and Policy. 22, 1-16. Article is located at www.umanitoba.ca/publications/cjeap/articles/kourit.htm

Merino, B. J. (1983). Language loss in bilingual Chicano children. Journal of Applied Developmental Psychology, 4, 277-294.

Okamura-Bichard, F. (1985). Mother tongue maintenance and second language learning: A case of Japanese children. Language Learning, 35, 63-89.

Pan, B. A., \& Berko-Gleason, J. (1986). The study of language loss: Models and hypotheses for an emerging discipline. Applied Psycholinguistics, 7, 193-206.

Ruiz-de-Velasco, J., M. Fix, \& B. Chu Clewell. (2000). Overlooked and underserved: Immigrant students in U.S. secondary schools. Washington, DC: Urban Institute.

Schecter, S., \& Bayley, R. (1997). Language socialization practices and cultural identity: Case studies of Mexican-descent families in California and Texas. TESOL Quarterly, 31, 513-541. 
Taft, R. \& Cahill, D. (1989). Mother tongue maintenance in Lebanese immigrant families in Australia. Journal of Multilingual and Multicultural Development, 10, 129-144.

Tse, L. (1998). Ethnic identity formation and its implications for heritage language development. In S.D. Krashen, L. Tse \& J. McQuillan, Heritage language development (pp. 15-30). Culver City, CA: Language Education Associates.

Tse, L. (2001). Why don't they learn English? Separating fact from fallacy in the U.S. language debate. New York, NY: Teachers College Press.

Wong Fillmore, L. (1991). When learning a second language means losing the first. Early Childhood Research Quarterly, 6, 323-346. 
Sandra Kouritzin is an Associate professor of Teaching English as a second language in the Department of Curriculum, Teaching and Learning at the University of Manitoba. 